DIKDAS MATAPPA: Jurnal Ilmu Pendidikan Dasar

Vol, 2. No, 2. September 2019 p-ISSN: 2620-5246 dan e-ISSN: 2620-6307

Link: http://journal.stkip-andi-matappa.ac.id/index.php/dikdas

(1) This work is licensed under a Creative Commons Attribution

4.0 International License

\title{
PENINGKATAN KESADARAN METAKOGNITIF DAN HASIL BELAJAR MELALUI PENERAPAN MODEL DISCOVERY LEARNING PADA PEMBELAJARAN IPS
}

\author{
Sri Hastati ${ }^{1 *}$, Erwin Nurdiasyah ${ }^{2}$ \\ ${ }^{1}$ Dosen PGSD Universitas Islam Makassar \\ Email: hastati1802@gmail.com \\ ${ }^{2}$ Dosen PGSD Universitas Islam Makassar \\ Email: erwinfkipuim@gmail.com
}

\begin{abstract}
This study aims to determine (i) increasing metacognitive awareness and learning outcomes through the application of discovery learning models in IPS learning in class $v$ sdn no. 79 sawakong towa takalar. Types of classroom action research. The focus of research is teacher and student factors, metacognitive awareness, and learning outcomes. The subjects of this study were fifth grade students at SDN No. 79 Sawakong Towa Takalar with 27 students in the 2019/2020 school year. Data collection techniques were observation, tests, questionnaires and documentation. Data analysis techniques are quantitative and qualitative analysis. Based on the results of research the actions taken by researchers in class V SDN No. 79 Sawakong Towa Takalar, it can be concluded that the implementation of the discovery learning model is one of the learning models that can be applied to increase the metacognitive awareness of students so that students are encouraged to think of good ways of learning to do. By implementing the discovery learning model the activity and student learning outcomes significantly increased in social studies learning in class V SDN No. 79 Sawakong Towa Takalar. Each cycle has increased and in the learning process students gain meaningful knowledge.
\end{abstract}

Keywords: discovery learning model; metacognitive awareness; learning outcomes.

Abstrak. Penelitian ini bertujuan mengetahui (i) peningkatan kesadaran metakognitif dan hasil belajar melalui penerapan model discovery learning pada pembelajaran ips di kelas $v$ sdn no. 79 sawakong towa takalar. Jenis penelitian tindakan kelas (classroom action research). Fokus penelitian adalah faktor guru dan siswa, kesadaran metakognitif, dan hasil belajar. Subjek dari penelitian ini adalah siswa kelas V SDN No. 79 Sawakong Towa Takalar dengan jumlah 27 siswa pada tahun ajaran 2019/2020. Teknik pengumpulan data observasi, tes, angket dan dokumentasi. Teknik analisis data yaitu analisis kuantitatif dan kualitatif. Berdasarkan hasil penelitian tindakan yang telah dilakukan peneliti di kelas V SDN No. 79 Sawakong Towa Takalar, maka dapat disimpulkan bahwa pengimplementasian model discovery learning merupakan salah satu model pembelajaran yang dapat diterapkan untuk meningkatkan kesadaran metakognitif peserta didik sehingga peserta didik terdorong untuk memikirkan cara belajar yang baik untuk dilakukan. Dengan pengimplementasian model discovery learning Aktivitas dan hasil belajar siswa meningkat secara signifikan pada pembelajaran IPS di kelas V SDN No. 79 Sawakong Towa Takalar. Setiap siklusnya mengalami peningkatan dan pada proses pembelajarnnya peserta didik mendapat pengetahuan yang bermakna.

Kata Kunci: model discovery learning, kesadaran metakognitif, hasil belajar 


\section{PENDAHULUAN}

Pemilihan model pembelajaran yang menarik dapat berpengaruh pada diri peserta didik, yaitu dengan melibatkan peserta didik untuk terlibat lebih aktif dalam proses pembelajaran. Guru berperan sebagai fasilitator dan motivator dalam pembelajaran (Tapantoko, 2011). Namun demikian, pembelajaran yang berlangsung selama ini masih didominasi pembelajaran yang berpusat pada guru. Hal tersebut sejalan dengan pendapat Hala dan Taiyeb (2016) bahwa proses pembelajaran yang digunakan guru belum menggunakan model pembelajaran yang tepat, sehingga masih menggunakan model pembelajaran langsung (direct instruction) yang berpusat pada guru. Dengan model pembelajaran yang berpusat pada guru membuat suasana pembelajaran menjadi tidak kondusif sehingga peserta didik menjadi pasif. Begitu juga, dalam proses pembelajaran peserta didik bukan lagi dipandang sebagai subyek pembelajaran melainkan obyek pembelajaran (Hamid, et al. 2015).

Menurut Sukaisih \& Muhali (2013) permasalahan lain yang kerap muncul adalah siswa cenderung terkesan apa adanya (berlangsung secara alami) dalam belajar. Misalnya apabila siswa dihadapkan pada permasalahan pembelajaran, mereka berupaya untuk menyelesaikan semampunya tanpa berpikir tentang tingkat kebenaran penyelesaian permasalahan tersebut dan jarang siswa yang melakukan evaluasi tentang strategi penyelesaian masalah yang mereka gunakan. Hal ini mengindikasikan rendahnya tingkat kesadaran metakognitif siswa.

Siswa dengan kesadaran metakognitif yang baik akan mampu menjadi pebelajar yang mandiri. Siswa mampu merencanakan, memonitor, dan mengevaluasi dirinya sendiri dalam kegiatan belajarnya. Aktivitas metakognitif terjadi saat murid secara sadar menyesuaikan dan mengelola strategi pemikiran mereka pada saat memecahkan masalah dan memikirkan suatu tujuan (Arifin \& Saenab, 2014).

Kondisi nyata yang dikemukakan tersebut di atas, akan berdampak negatif dengan terciptanya pembelajaran yang tidak efektif. Ketidakefektifan pembelajaran tersebut disebabkan oleh orientasi pembelajaran yang terlalu berpusat pada guru (teacher centered). Pembelajaran teacher centered menyebabkan peserta didik hanya dapat mengingat $70 \%$ materi pelajaran dalam sepuluh menit pertama, sedangkan dalam sepuluh menit terakhir mereka hanya dapat mengingat $20 \%$ materi pembelajaran (Silberman, 2013).

Berdasarkan hasil observasi dan wawancara dengan guru kelas $\mathrm{V}$ di SDN No. 79 Sawakong Towa Takalar diperoleh informasi bahwa terdapat permasalahan yang dihadapi guru dalam proses pembelajaran. Permasalahan tersebut yaitu kesulitan peserta didik memahami materi pelajaran IPS. Hal ini menyebabkan kurangnya antusias peserta didik dalam memperhatikan pelajaran dan kesulitan peserta didik dalam menjawab pertanyaan yang diajukan guru sehingga menyebabkan rendahnya hasil belajar siswa.

Salah satu model pembelajaran yang dapat dipilih untuk mengatasi permasalahan tersebut yaitu model discovery learning. Dalam model pembelajaran discovery learning peserta didik dituntut untuk aktif dalam membangun pengetahuannya sendiri. Guru tidak menyajikan materi secara utuh, tetapi guru hanya menyajikan suatu fakta kasus yang mencerminkan suatu konsep atau prinsip, kemudian peserta didik dibimbing untuk menyimpulkan prinsip dari pelajaran tersebut (Balim, 2009).

Berdasarkan latar belakang masalah di atas, maka dapat dikemukakan rumusan masalah penelitian ini adalah "apakah implementasi model discovery learning mampu meningkatkan kesadaran metakognitif dan hasil belajar peserta didik pada pembelajaran IPS di SD?

Berdasarkan rumusan masalah di atas maka tujuan penelitian ini yaitu mengimplementasikan model discovery learning untuk meningkatkan kesadaran metakognitif dan hasil belajar peserta didik pada pembelajaran IPS di kelas V SDN No. 79 Sawakong Towa Takalar.

Menurut Kristin \& Rahayu,

discovery learning sebagai suatu model untuk mengembangkan cara belajar peserta didik dengan menemukan sendiri, menyelidiki 
sendiri, sehingga hasil yang diperoleh akan tahan lama dalam ingatan tidak akan mudah dilupakan oleh peserta didik. Dengan belajar penemuan peserta didik juga bisa berpikir lebih kritis dan mencoba memecahkan sendiri masalah yang dihadapi. Menurut Putri dkk (2012) metakognitif merupakan kesadaran untuk berpikir, merencanakan, memantau dan merefleksikan tugas-tugas yang diselesaikan. Hasil belajar dapat dijelaskan dengan memahami dua kata yang membentuknya, yaitu "hasil" dan "belajar". Pengertian hasil (product) menunjuk pada suatu perolehan akibat dilakukannya suatu aktifitas atau proses yang mengakibatkan berubahnya input secara fungsional (Purwanto, 2011).

Berdasarkan tinjauan pustaka di atas, maka hipotesis tindakan yang diajukan dalam penelitian tindakan kelas ini adalah "jika model Discovery Learning kooperatif diterapkan pada pelajaran IPS, makakesadaran kognitif dan hasil belajar IPS siswa kelas V SDN No. 79 Sawakong Towa Takalar dapat meningkat".

\section{METODE}

Penelitian ini termasuk jenis penelitian tindakan kelas (classroom action research). Fokus penelitian adalah faktor guru: Pelaksanaan penelitian ini, guru yang melaksanakan tindakan serta akan dilihat bagaimana cara menerapkan model discovery learning. Semua tindakan guru akan diamati dengan cermat agar dapat diketahui aspekaspek apa saja yang menjadi kekurangan dan kelebihan dalam menerapkan model tersebut; siswa: Penelitian ini, siswa yang menjadi subyek penelitian dan akan dilihat bagaimana keaktifan, kerja sama serta keefektifan proses belajar siswa dalam melaksanakan dan menyelesaikan setiap tugastugas yang diberikan melalui penerapan model discovery learning, kesadaran metakognitif: Kesadaran metakognitif diukur menggunakan angket (Metacognitive Skill Inventory); dan hasil belajar: Hasil belajar yang dimaksud yaitu dengan melihat/mengamati hasil tes yang diperoleh siswa diakhir setiap siklus untuk mengetahui adanya perubahan yang signifikan dari hasil belajar IPS siswa melalui penerapan model Disscovery learning. Penelitian ini dilaksanakan di kelas V SDN No. 79 Sawakong Towa Takalar. Subjek dari penelitian ini adalah siswa kelas V SDN No. 79 Sawakong Towa Takalar, dengan jumlah 27 siswa yang aktif dan terdaftar pada tahun ajaran 2019/2020. Teknik pengumpulan data yang digunakan dalam penelitian ini yaitu observasi, tes, angket, dokumentasi. Data yang diperoleh dianalisis dengan menggunakan analisis kuantitatif dan kualitatif. Data mengenai hasil belajar siswa dianalisis secara kuantitatif. Untuk analisis kuantitatif digunakan analisis statistik deskriptif sedangkan data yang hasil observasi dan hasil angket dianalisis secara kualitatif.

\section{HASIL DAN PEMBAHASAN}

Hasil

Hasil penelitian terdiri dari temuan keberhasilan peneliti dalam menerapkan model discovery learning untuk meningkatkan kesadaran metakognitif dan hasil belajar peserta didik pada pembelajaran IPS di kelas V SDN No. 79 Sawakong Towa Takalar.

\section{Data Tindakan siklus I}

Penelitian dilaksanakan mulai tanggal 22 juli sampai dengan 22 Agustus di SDN No. 79 Sawakong Towa Takalar. Penelitian ini terdiri dari 4 pertemuan materi dan 2 pertemuan test sehingga menjadi 6 pertemuan. Penelitian ini dibagi menjadi 2 siklus, setiap siklusnya terdiri dari 2 kali pertemuan penerapan model discovery learning dan 1 kali pertemuan pemberian tes hasil belajar dan angket kesadaran metakognitif. Metode pelaksanaan pembelajarannya menggunakan prinsip-prinsip penelitian tindakan kelas yang terdiri dari beberapa siklus dimana masing-masing siklus melalui empat tahap yaitu perencanaan, tahap pelaksanaan tindakan, tahap observasi dan tahap refleksi.

\section{a. Perencanaan}

Tahap perencanaan pada siklus I dilaksanakan pada 23 juli 2019 melakukan perkenalan dengan kepala sekolah beserta beberapa guru di SDN No. 79 Sawakong Towa Takalar. Melalui kepala sekolah dan guru kelas V peneliti meminta data siswa yang menjadi subjek penelitian dan data sekolah. Kemudian 
guru kelas bersama peneliti memeberikan masukan tentang hal-hal yang perlu diperhatikan antara lain :

1) Mempelajarai kurikulum untuk kelas $V$ sekolah dasar. Kurikulum yang digunakan pada SDN No. 79 Sawakong Towa Takalar adalah Kurikulum 2013.

2) Membuat rencana pelaksanaan pembelajaran (RPP) berdasarkan laporan guru kelas bahwa pokok bahasan tentang tema 1 Organ Gerak Hewan Dan Manusia.

3) Membuat lembar observasi untuk melihat aktivitas guru dan belajar siswa pada saat proses pembelajaran menerapkan model discovery learning.

4) Merancang dan mebuat soal sebagai instrumen hasil belajar dan angket sebagai instrument kesadaran metakognitif.

\section{b. Pelaksanaan Tindakan}

Langkah-langkah pelaksanaan siklus I dilakukan pada 25 dan 29 juli 2019 merupakan tindakan/kegiatan guru dalam upaya meningkatkan kesadaran metakognitif dan hasil belajar IPS melalui penerapan model discovery learning dengan menerapkan langkah-langkah berikut:

\section{Kegiatan Awal}

Pada kegiatan ini guru mempersiapkan materi pelajaran, tempat duduk siswa dan mengalihkan perhatian siswa untuk memperhatikan pelajaran IPS. Kegiatan selanjutnya kelas mulai dibuka dengan salam, menanyakan kabar dan mengecek kehadiran siswa, dilanjutkan lagi dengan do'a dipimpin oleh salah seorang siswa. Siswa yang diminta membaca do'a adalah siswa siswa yang hari ini datang paling awal. (Menghargai kedisiplikan siswa).

Kegiatan Inti

Pada kegiatan ini untuk tahap stimulus guru memberikan kesempatan kepada siswa untuk bertanya dan memberikan pendapat mengenai kenampakan alam dan kondisi geografis di wilayah tempat tinggalnya. Membagi murid dalam tim yang beranggotakan 4-5 orang, masing-masing tim terdiri dari laki-laki dan perempuan dengan kemampuan akdemik yang beragam. Pada tahap Problem statement siswa diminta mengidentifikasi sebanyak mungkin masalah yang relevan dengan bahan pelajaran dalam hal ini membuat daftar kebutuhan anggota keluarganya yang diperoleh dari daerah lain. Guru membagikan teks yang berisi bacaan tentang kenampakan alam dan kondisi geografis Indonesia. Guru membagikan LK pada setiap kelompok. Peserta didik dalam kelompok berdiskusi membahas masalah dalam LK sebagai bagian dari tahap Data collection \& Data processing. Alternatif Pelaksanaan Diskusi:

- Guru menciptakan suasana interaktif dan atraktif dengan mengajak siswa melaksanakan diskusi secara klasikal

- Guru memberikan kesempatan kepada siswa untuk memilih para petugas diskusi, seperti pembawa acara, sekretaris/notulis, dan lain-lain. Sementara anak-anak yang lain bertindak sebagai peserta diskusi.

- Pembawa acara bertanggung jawab atas jalannya diskusi. Pembawa acara juga bertugas untuk membacakan pertanyaanpertanyaan untuk didiskusikan oleh peserta.

- Notulis bertugas untuk mencatat kejadiankejadian yang terjadi saat diskusi berlangsung, seperti pendapat-pendapat yang disampaikan oleh peserta diskusi. Notulis juga bertugas untuk membuat laporan dan kesimpulan hasil diskusi.

- Setiap peserta diskusi berhak mengemukakan pendapatnya berkaitan dengan pertanyaan-pertanyaan yang diajukan oleh pembawa acara.

- Guru membimbing siswa mengadakan pemeriksaan secara cermat untuk membuktikan benar tidaknya hipotesis yang ditetapkan sebelumnya yang merupakan tahap verifikasi

- Setelah siswa memberikan pendapatnya, guru mengonfirmasi pendapat-pendapat siswa. Kemudian guru memandu siswa untuk menarik kesimpulan sebagai bagian dari tahap Generalisasi.

\section{Kegiatan Akhir}

Kegiatan akhir ditandai dengan kegiatan guru memberikan penguatan dan kesimpulan. Siswa diberikan kesempatan bertanya dan menambahkan informasi dari siswa lainnya. Selanjutnya menyanyikan salah satu lagu daerah untuk menumbuhkan nasionalisme, persatuan, dan toleransi. Kemudian salam dan do'a penutup di pimpin oleh salah satu siswa. 


\section{c. Observasi}

\section{1) Hasil observasi aktivitas guru}

Keberhasilan tindakan pada siklus I ini diamati selama proses pelaksanaan dan setelah tindakan. Fokus pengamatan adalah perilaku guru dan siswa dengan menggunakan lembar observasi tindakan siklus I. Adapun aspek yang diamati adalah aktivitas guru dan siswa dalam proses pembelajaran yang disesuaikan dengan langkah-langkah model discovery learning yaitu Stimulus, Problem statement, Data collection, Data processing, verifikasi, dan Generalisasi. Dari hasil observasi guru pada siklus I menunjukkan bahwa guru belum melaksanakan semua indikator yang direncanakan sesuai dengan langkah-langkah model discovery learning. Ada 3 indikator telah dilaksanakan oleh guru dengan baik yaitu

1) Memberikan pertanyaan yang merangsang berpikir peserta didik, menganjurkan dan mendorongnya untuk membaca buku dan aktivitas belajar lain yang mengarah pada persiapan pemecahan masalah. (stimulus). Hal ini terlihat pada saat proses belajar mengajar, guru menstimulus ide, gagasan, dan motivasi siswa, memberikan kesempatan kepada siswa untuk bertanya dan memberikan pendapat mengenai kenampakan alam dan kondisi geografis di wilayah tempat tinggalnya.

2) Memberikan kesempatan kepada peserta didik untuk mengidentifikasi sebanyak mungkin masalah yang relevan dengan bahan pelajaran, kemudian memilih dan merumuskannya dalam bentuk hipotesis (Problem statement). Hal ini terlihat saat guru meminta siswa membuat daftar kebutuhan anggota keluarganya yang diperoleh dari daerah lain serta merangkumnya dalam bentuk hipotesis.

3) memberikan kesempatan kepada peserta didik mengumpulkan informasi yang relevan sebanyak-banyaknya untuk membuktikan benar tidaknya hipotesis tersebut (Data collection)

Adapun 3 indikator yang belum dilaksanakan secara optimal yaitu:

1) Guru membimbing siswa mengadakan pemeriksaan secara cermat untuk membuktikan benar tidaknya hipotesis yang ditetapkan dan dihubungkan dengan hasil dan pengolahan data (verifikasi).

2) Guru membimbing peserta didik mengolah data yang telah diperoleh peserta didik melalui kegiatan wawancara, observasi dan lain-lain. Data tersebut kemudian diinterpretasikan (Data processing);

3) Guru membimbing peserta didik mengadakan penarikan kesimpulan untuk dijadikan prinsip umum yang berlaku untuk semua kejadian atau masalah yang sama dengan memperhatikan hasil verifikasi (generalisasi).

Berdasarkan hasil observasi data tindakan siklus I, dapat disimpulkan bahwa rencana pembelajaran dengan menggunakan model discovery learning yaitu guru belum mampu melaksanakan secara maksimal keseluruhan indikator yang direncanakan. Berdasarkan hal tersebut maka kinerja yang dilakukan oleh guru selama proses pembelajaran berlangsung dapat dikategorikan cukup baik.

\section{2) Hasil observasi aktivitas siswa}

Aktivitas guru pada tindakan siklus I berpengaruh pada keberhasilan siswa dalam melakukan aktivitas belajar, serta berpengaruh pada peningkatan pemahaman siswa. Pada tindakan siklus I diharapkan siswa mampu melakukan 6 indikator yang telah ditetapkan untuk keseluruhan siswa kelas V SDN No. 79 Sawakong Towa Takalar yang berjumlah 27 orang.

Berdasarkan data hasil observasi pengamat terhadap subjek penelitian yang berjumlah 27 orang siswa pada tindakan siklus I menunjukkan bahwa, dari 6 indikator yang direncanakan terdapat 2 indikator yang dapat dilaksanakan dengan baik yaitu:

1) Peserta didik mengidentifikasi masalah kemudian menyusun hipotesis sesuai arahan guru

2) Peserta didik mengumpulkan informasi yang relevan sebanyak-banyaknya untuk membuktikan benar tidaknya hipotesis yang telah disusun

Selama proses pembelajaran berlangsung, terdapat 4 indikator pembelajaran yang belum dilaksanakan oleh siswa yaitu: 
1) Siswa belum melakukan secara maksimal bertanya, menjawab dan mengemukakan pendapat. Hal ini dikarenakan siswa kadang malu berbicara di depan temantemannya, ragu akan jawabannya, takut salah dan dimarahi ibu guru.

2) Peserta didik tidak mengolah data yang telah diperoleh karena belum tau langkahlangkah yang harus dilakukan

3) Peserta didik tidak mengadakan pemeriksaan secara cermat untuk membuktikan benar tidaknya hipotesis yang ditetapkan dan dihubungkan dengan hasil dan pengolahan data karena tidak ada instruksi dari guru.

4) Peserta didik tidak mengadakan penarikan kesimpulan.

Berdasarkan observasi tersebut, maka aktivitas siswa Kelas V selama proses pembelajaran dapat dikategorikan cukup. Hal ini disebabkan karena selama proses pembelajaran siswa kurang memberikan respon dan lebih banyak melakukan aktivitas lain pada saat proses pembelajaran berlangsung. Oleh karena itu, data observasi siswa tersebut akan dianalisis sehingga akan menjadi bahan refleksi pada pembelajaran berikutnya pada tindakan siklus II.

\section{d. Analisis tindakan siklus I}

Melihat hasil dari siklus I tampak bahwa masih ada siswa yang belum memahami materi pada tema 1 dengan menggunakan model discovery learning. Hal ini terlihat dari pemahaman siswa dalam mengemukakan jawaban dari soal yang diberikan secara tertulis, belum sesuai dengan indikator keberhasilan yang telah ditetapkan yaitu apabila siswa secara keseluruhan memperoleh nilai rata-rata kelas $75 \%$ dengan nilai setiap subjek penelitian memperoleh nilai paling rendah 75 . Dari data hasil jawaban siswa tersebut terungkap bahwa siswa belum dapat memahami materi pada tema 1 dengan baik. Selengkapnya dapat dilihat pada tabel 4.1.

Tabel 4.1. Hasil belajar siswa pada siklus I

\begin{tabular}{llll}
\hline Interval & Hasil Belajar Murid & Frekuensi & Persentase \\
\hline $85-100$ & Sangat Tinggi & 7 & $25,93 \%$ \\
\hline $65-84$ & Tinggi & 10 & $37,04 \%$ \\
\hline $55-64$ & Sedang & 8 & $29,63 \%$ \\
\hline $35-54$ & Rendah & 1 & $3,70 \%$ \\
\hline $0-34$ & Sangat Rendah & 1 & $3,70 \%$ \\
\hline Jumlah & & 27 & $100 \%$ \\
\hline
\end{tabular}

Berdasarkan tabel 4.1 tersebut, tampak bahwa dari 27 siswa terdapat 7 siswa tinggi dengan persentase $25,93 \%, 10$ siswa dalam kategori tinggi dengan persentase $37,04 \%, 8$ siswa dalam kategori sedang dengan persentase 29,63\%, 1 siswa dalam kategori rendah dengan persentase $3,70 \%$ dan 1 siswa dalam kategori sangat rendah dengan persentase $3,70 \%$.

Berdasarkan hasil belajar pada siklus I, maka persentase ketuntasan belajar siswa dapat dilihat pada tabel dibawah ini:

Tabel 4.2. Persentase ketuntasan belajar siswa pada siklus I

\begin{tabular}{llll}
\hline Kriteria Ketuntasan & Kategori & Frekuensi & Persentase \\
\hline $0-75$ & Tidak Tuntas & 16 & $59,26 \%$ \\
\hline $75-100$ & Tuntas & 11 & $40,74 \%$ \\
\hline Jumlah & & 27 & $100 \%$ \\
\hline
\end{tabular}

Berdasarkan tabel diatas menunjukkan persentase ketuntasan belajar siswa pada siklus I adalah 59,26\% dalam kategori tidak tuntas dengan jumlah frekuensi 16 dan 40,74\% dalam kategori tuntas dengan jumlah frekuensi 11. 
Untuk hasil analisis angket Kesadaran Metakognitif peneliti selanjutnya melakukan analisis data yang telah diisi oleh siswa kemudian dikumpulkan, diolah untuk selanjutnya diinterpretasikan berdasarkan hasil instrumen tersebut. Hasil interpretasi angket yang telah diberikan sebelum dilaksanakannya siklus I yakni pada hari rabu tanggal 24 juli
2019 dibandingkan dengan angket berikutnya setelah siklus I selesai yakni pada tanggal 30 juli 2019 untuk melihat bagaimana perubahan yang terjadi setelah penerapan model discovery learning dalam siklus I. Adapun perbandingan hasil angket yang diberikan sebelum dan sesudah siklus I dapat dilihat pada tabel berikut:

Tabel 4. 3: Hasil analisis data angket tentang Kesadaran Metakognitif siswa dari pelaksanaan siklus I

\begin{tabular}{cccccc}
\hline Interval & f0 & Persentase & f1 & Persentase & Interpretasi \\
\hline $81-100$ & 3 & $11,11 \%$ & 4 & $14,81 \%$ & Berkembang sangat baik \\
$61-80$ & 7 & $25,93 \%$ & 7 & $25,93 \%$ & Berkembang baik \\
$41-60$ & 9 & $33,33 \%$ & 12 & $44,44 \%$ & Mulai Berkembang \\
$21-40$ & 8 & $29,63 \%$ & 4 & $14,81 \%$ & Belum begitu berkembang \\
$0-20$ & 0 & $0 \%$ & 0 & $0 \%$ & Masih beresiko \\
$\sum$ & 27 & $100 \%$ & 27 & $100 \%$ & \\
\hline
\end{tabular}

Sumber: hasil analisis angket setelah siklus I

Berdasarkan hasil analisis angket diketahui bahwa terjadi perubahan setelah pelaksanaan siklus I. Untuk siswa dengan kategori Berkembang sangat baik sebelum diberikan tindakan pada siklus I sebanyak 3 orang $(11,11 \%)$ setelah pelaksanaan siklus I berubah menjadi 4 orang $(25,93 \%)$ hal ini berarti terjadi perubahan, untuk siswa dengan kategori Berkembang baik sebelum pemberian tindakan pada siklus I sebanyak 7 orang $(25,93 \%)$ dan setelah pelaksanaan siklus I tetap, untuk siswa dengan kategori Mulai Berkembang sebelum pelaksanaan tindakan pada siklus I sebanyak 9 orang $(33,33 \%)$ setelah pelaksanaan siklus I menjadi 12 orang $(44,44 \%)$ ini berarti terjadi perubahan yang meningkat, untuk siswa dengan kategori Belum begitu berkembang sebelum pelaksanaan tindakan pada siklus I sebanyak 8 orang $(29,63 \%)$ namun setelah pelaksanaan siklus I menjadi 4 orang $(14,81 \%)$ terjadi penurunan, sedangkan untuk kategori masih beresiko dimana sebelum pelaksanaan tindakan pada siklus I maupun setelah pelaksanaan siklus I masih tetap dan belum terjadi perubahan dengan jumlah siswa tidak ada $(0 \%)$.

Berdasarkan hasil analisis data yang telah dilakukan dari angket maka peneliti dapat menarik kesimpulan sementara dari pelaksanaan siklus pertama dimana telah terjadi perubahan pada siswa namun peneliti akan melanjutkan ketahap berikutnya melalui pelaksanaan siklus kedua untuk memperoleh perubahan yang lebih memuaskan dengan melakukan beberapa perubahan proses kegiatan.

\section{e. Refleksi tindakan siklus I}

Di awal pertemuan pertama dan kedua sebagian siswa belum dapat mengikuti pembelajaran ini dengan baik, hal ini disebabkan karena siswa belum terbiasa dengan pembelajaran ini dan masih perlu beradaptasi. Dari hasil pengamatan sering terjadi keributan terutama dalam pembagian kelompok para siswa ingin membentuk kelompok sendiri, selain menimbulkan keributan juga membutuhkan waktu yang banyak untuk mengarahkan siswa untuk berdiskusi pada tempatnya, beberapa siswa laki-laki sering keluar masuk kelas tanpa menghiraukan guru, penyebab yang lain adalah banyaknya waktu yang terbuang karena siswa masih bingung dengan pembelajaran ini.

Secara umum selama penelitian berlangsung hingga akhir siklus I semangat belajar siswa semakin nampak, mereka semakin biasa bekerjasama dengan anggota bakelompoknya berkat kesabaran guru mengatur jalannya diskusi. Pada akhir siklus I siswa diberi tes untuk menentukan sejauh mana kemampuan mereka atas materi yang telah diberikan dan dibahas selama siklus I. Pembagian angket 
juga dilakukan untuk mengukur tingkat kesadaran metakognitif. Pelaksanaan berjalan dengan lancar meskipun masih ada siswa yang bekerjasama dengan temannya. Demikian pula pada proses belajar mengajar rmasih terlihat siswa yang masih pasif, siswa yang demikian umumnya kurang memahami materi yang diberikan.

Maka dari itu, perlu dilanjutkan pada siklus II, dengan perencanaan sebagai berikut:

a) Mendiskusikan kekurangan-kekurangan tindakan pada siklus I yang kemudian peneliti bersama guru mencari solusi

b) Mengevaluasi hasil obsrvasi guru dengan menyamakan persepsi penerapan langkahlangkah model discovery learning.

c) Memberikan motivasi kepada siswa agar lebih aktif lagi dalam pembelajaran.

d) Memancing keberanian siswa dalam mengungkapkan pertanyaan dan memberi jawaban

e) Lebih intensif membimbing kelompok yang mengalami kesulitan.

f) Memberikan pengakuan dan penghargaan (reward).

\section{Data tindakan siklus II}

\section{a. Perencanaan Tindakan Siklus 1I}

Langkah-langkah yang dilakukan dalam siklus II ini pada umumnya merupakan hasil refleksi pada siklus I, selanjutnya dikembangkan dan dimodifikasi tahapan-tahapan yang ada pada siklus I dengan beberapa perbaikan, evaluasi, dan penambahan sesuai dengan kenyataan di lapangan.

Rumusan hasil perencanaan pada siklus II adalah sebagai berikut:

1) Pelaksanaan tindakan siklus II dilakukan sebanyak dua kali pertemuan.

2) Langkah-langkah pelaksanaan pembelajaran pada setiap pertemuan pada siklus II mengacu pada Rancangan Program Pembelajaran (RPP) yang telah dibuat.

3) Model pembelajaran yang diterapkan dalam proses pembelajaran adalah pembelajaran discovery learning.

4) Pada setiap akhir pertemuan, siswa dievaluasi dengan memberikan angket berupa pernyataan dan tes berupa pertanyaan yang dikerjakan secara individual.
5) Selama pelaksanaan tindakan, peneliti melakukan pengamatan terhadap perilaku siswa selama proses pembelajaran berlangsung dan pengamatan terhadap kinerja pelaksanaan tindakan dengan berpedoman pada lembar panduan observasi yang telah dibuat.

\section{b. Pelaksanaan Tindakan}

Kegiatan pelaksanaan tindakan berpedoman pada perencanaan kegiatan pembelajaran yang di desain dalam bentuk Rencana Pelaksanaan Pembelajaran (RPP). Pelaksanaan pembelajaran dilakukan pada hari senin dan Kamis tanggal 5 agustus dan 8 agustus 2019. Adapun langkah-langkah pada proses pembelajaran IPS yang dilakukan dengan tiga tahap kegiatan yaitu kegiatan awal, kegiatan inti dan kegiatan akhir. Kegiatan tersebut dapat diuraikan sebagai berikut:

\section{Kegiatan Awal}

Kelas mulai dibuka dengan salam, menanyakan kabar dan mengecek kehadiran siswa. Kelas dilanjutkan dengan do'a dipimpin oleh salah seorang siswa. Siswa yang diminta membaca do'a adalah siswa siswa yang hari ini datang paling awal. (Menghargai kedisiplikan siswa/PPK). Siswa diingatkan untuk selalu mengutamakan sikap disiplin setiap saat dan menfaatnya bagi tercapainya sita-cita. Selanjutnya Menyanyikan lagu Garuda Pancasila atau lagu nasional lainnya. Guru memberikan penguatan tentang pentingnya menanamkan semangat Nasionalisme. Tak lupa melakukan pembiasaan membaca/ menulis/ mendengarkan/ berbicara selama 1520 menit materi non pelajaran seperti tokoh dunia, kesehatan, kebersihan, makanan/minuman sehat, cerita inspirasi dan motivasi. Sebelum membacakan buku guru menjelaskan tujuan kegiatan literasi

\section{Kegiatan Inti}

Pada kegiatan ini untuk tahap stimulus di awal pembelajaran, guru menstimulus ide, gagasan, dan motivasi siswa dengan menunjukan gambar dan memberikan narasi tentang kekayaan yang dimiliki oleh bangsa Indonesia. Secara interaktif, guru memberikan penjelasan mengenai kekayaan sumber daya alam dan manusia yang dimiliki oleh bangsa Indonesia. Siswa mengamati gambar peta tentang kepadatan penduduk di Indonesia sebagai langkah pada tahap Problem statement yang 
selanjutnya diminta mengidentifikasi sebanyak mungkin masalah yang relevan dengan bahan pelajaran. Guru membagikan teks yang berisi bacaan tentang kenampakan alam dan kondisi geografis Indonesia. Guru membagikan LK pada setiap kelompok. Peserta didik dalam kelompok berdiskusi membahas masalah dalam LK sebagai bagian dari tahap Data collection \& Data processing. Guru membimbing siswa mengadakan pemeriksaan secara cermat untuk membuktikan benar tidaknya hipotesis yang ditetapkan sebelumnya yang merupakan tahap verifikasi. Setelah siswa memberikan pendapatnya, guru mengonfirmasi pendapatpendapat siswa. Kemudian guru memandu siswa untuk menarik kesimpulan sebagai bagian dari tahap Generalisasi.

Berdasarkan kegiatan inti tersebut dimana guru telah melaksanakan pembelajaran dengan baik sesuai dengan rencana karena guru sudah mampu mengatur waktu dalam menjelaskan materi pelajaran yang terangkum pada tema 1 subtema 2. Murid sudah mampu menyerap pelajaran dengan baik sehingga dapat mengerjakan tugas baik tugas kelompok maupun tugas individu yang diberikan oleh guru, murid tidak kebingungan lagi serta murid sudah paham dan senang dengan pelajaran yang mereka dapatkan tersebut.

\section{Kegiatan Akhir}

Pada kegiatan ini guru memberikan penguatan dan kesimpulan secara menyeluruh. Siswa diberikan kesempatan berbicara /bertanya dan menambahkan informasi dari siswa lainnya serta menyanyikan salah satu lagu daerah untuk menumbuhkan nasionalisme, persatuan, dan toleransi. Salam dan do'a penutup di pimpin oleh salah satu siswa.

\section{c. Hasil Observasi dan Temuan Tindakan Siklus II \\ 1) Hasil Observasi Aktivitas Guru}

Temuan penelitian tentang keberhasilan guru menerapkan model discovery learning pada tindakan siklus II menunjukkan bahwa, terdapat 6 indikator yang dapat dilaksanakan dengan baik yaitu: Memberikan pertanyaan yang merangsang berpikir peserta didik, menganjurkan dan mendorongnya untuk membaca buku dan aktivitas belajar lain yang mengarah pada persiapan pemecahan masalah. (stimulus). Memberikan kesempatan kepada peserta didik untuk mengidentifikasi sebanyak mungkin masalah yang relevan dengan bahan pelajaran, kemudian memilih dan merumuskannya dalam bentuk hipotesis (Problem statement). Memberikan kesempatan kepada peserta didik mengumpulkan informasi yang relevan sebanyak-banyaknya untuk membuktikan benar tidaknya hipotesis tersebut (Data collection). Membimbing peserta didik mengolah data yang telah diperoleh peserta didik melalui kegiatan wawancara, observasi dan lain-lain. Data tersebut kemudian diinterpretasikan (Data processing). Membimbing siswa mengadakan pemeriksaan secara cermat untuk membuktikan benar tidaknya hipotesis yang ditetapkan dan dihubungkan dengan hasil dan pengolahan data (verifikasi). Membimbing peserta didik mengadakan penarikan kesimpulan untuk dijadikan prinsip umum yang berlaku untuk semua kejadian atau masalah yang sama dengan memperhatikan hasil verifikasi (generalisasi).

Guru dapat melaksanakan keenam indikator disebabkan karena guru telah memahami secara mendalam tentang penerapan model discovery learning. Selain itu, kemampuan menguasai diskusi kelas membuat guru lebih mudah dalam membimbing siswa dalam proses pembelajaran.

Berdasarkan data dari tindakan siklus II dapat disimpulkan bahwa pencapaian implementasi rencana pembelajaran dengan menggunakan model discovery learning pada aspek guru adalah guru dapat melaksanakan ketujuh indikator tersebut. Berdasarkan hal tersebut maka kinerja yang dilakukan oleh guru selama proses pembelajaran berlangsung dapat dikategorikan sangat baik.

\section{2) Hasil Observasi Aktivitas Siswa}

Aktivitas guru pada tindakan siklus II berpengaruh pada keberhasilan siswa dalam melakukan aktivitas belajar, kesadaran metakognitif, serta bepengaruh pada peningkatan pemahaman siswa mengenai materi pelajaran. Pada tindakan siklus II diharapkan siswa mampu melakukan 6 indikator yang telah ditetapkan untuk 
keseluruhan siswa kelas IV yang berjumlah 27 orang siswa.

Berdasarkan data hasil observasi pengamat terhadap siswa kelas $\mathrm{V}$ sebagai subjek penelitian pada tindakan siklus II menunjukkan bahwa dari 6 indikator yang direncanakan, siswa telah dapat melaksanakan keenam indikator tersebut dengan baik. Berdasarkan observasi siswa tersebut, maka aktivitas siswa selama proses pembelajaran berlangsung dapat dikategorikan Sangat Baik d. Analisis tindakan siklus II

Melihat hasil dari siklus II ditemukan sudah tidak ada murid-murid yang kurang aktif dan kurang memahami materi yang diberikan atau dalam mengerjakan soal dan diskusi kelompok walaupun tidak semua murid mendapatkan nilai maksimal atau 100 namun target yang diinginkan sudah tercapai maka penelitian dihentikan pada siklus II. Dari data hasil jawaban siswa tersebut terungkap bahwa hasil belajar yang diperoleh siswa sangat baik. Selengkapnya lihat pada tabel 4.4.

Tabel 4.4. Hasil belajar siswa pada siklus II

\begin{tabular}{llll}
\hline Interval & Hasil Belajar Murid & Frekuensi & Persentase \\
\hline $85-100$ & Sangat Tinggi & 10 & $37,04 \%$ \\
\hline $65-84$ & Tinggi & 16 & $59,26 \%$ \\
\hline $55-64$ & Sedang & 1 & $3,70 \%$ \\
\hline $35-54$ & Rendah & 0 & $0 \%$ \\
\hline $0-34$ & Sangat Rendah & 0 & $0 \%$ \\
\hline Jumlah & & 27 & $100 \%$ \\
\hline
\end{tabular}

Berdasarkan tabel 4.3 tersebut, tampak bahwa dari 25 siswa terdapat 10 siswa sangat tinggi dengan persentase $37,04 \%, 16$ siswa dalam kategori tinggi dengan persentase 59,26\%, 1 siswa dalam kategori sedang dengan persentase $3,70 \%$, dan tidak ada siswa siswa dalam kategori rendah dan sangat rendah.

Berdasarkan hasil belajar pada siklus II, maka persentase ketuntasan belajar siswa dapat dilihat pada tabel dibawah ini:

Tabel 4.5. Persentase ketuntasan belajar siswa pada siklus II

\begin{tabular}{llll}
\hline Kriteria Ketuntasan & Kategori & Frekuensi & Persentase \\
\hline $0-75$ & Tidak Tuntas & 2 & $20,83 \%$ \\
\hline $75-100$ & Tuntas & 25 & $79,19 \%$ \\
\hline & Jumlah & 27 & $100 \%$ \\
\hline
\end{tabular}

Berdasarkan tabel diatas menunjukkan persentase ketuntasan belajar siswa pada siklus II adalah $92,59 \%$ tuntas dengan jumlah frekuensi 25 dan $7,41 \%$ tidak tuntas dengan jumlah frekuensi 2. Selanjutnya peneliti kembali menganalisis hasil angket yang telah diberikan kepada siswa setelah pelaksanaan siklus II kemudian membandingkan dengan hasil angket yang telah diberikan sebelumnya. Adapun perbandingan hasil angket yang diberikan setelah siklus I dan setelah siklus II dapat dilihat pada tabel berikut:

Tabel 4. 6: Hasil analisis data angket tentang Kesadaran Metakognitif siswa dari pelaksanaan siklus II

\begin{tabular}{cccccc}
\hline Interval & f0 & Persentase & f1 & Persentase & Interpretasi \\
\hline $81-100$ & 4 & $14,81 \%$ & 7 & $25,93 \%$ & Berkembang sangat baik \\
$61-80$ & 7 & $25,93 \%$ & 13 & $48,15 \%$ & Berkembang baik \\
$41-60$ & 12 & $44,44 \%$ & 7 & $25,93 \%$ & Mulai Berkembang \\
$21-40$ & 4 & $14,81 \%$ & 0 & $0 \%$ & Belum begitu berkembang \\
$0-20$ & 0 & $0 \%$ & 0 & $0 \%$ & Masih beresiko \\
$\sum$ & 27 & $100 \%$ & 27 & $100 \%$ & \\
\hline
\end{tabular}

Sumber: hasil analisis angket setelah siklus II 
Berdasarkan hasil analisis angket diketahui bahwa terjadi perubahan setelah pelaksanaan siklus II. Untuk siswa dengan kategori Berkembang sangat baik sebelum diberikan tindakan pada siklus II sebanyak 4 orang $(14,81 \%)$ setelah pelaksanaan siklus II berubah menjadi 7 orang $(25,93 \%)$ hal ini berarti terjadi perubahan, untuk siswa dengan kategori Berkembang baik sebelum pemberian tindakan pada siklus II sebanyak 7 orang $(25,93 \%)$ setelah pelaksanaan siklus II berubah menjadi 13 orang $(48,15 \%)$ hal ini berarti terjadi peningkatan, untuk siswa dengan kategori Mulai Berkembang sebelum pelaksanaan tindakan pada siklus II sebanyak 12 orang $(44,44 \%)$ setelah pelaksanaan siklus II menjadi 7 orang $(25,93 \%)$ ini berarti terjadi penurunan, untuk siswa dengan kategori Belum begitu berkembang sebelum pelaksanaan tindakan pada siklus II sebanyak 4 orang $(14,81 \%)$ namun setelah pelaksanaan siklus II tidak ada lagi yang berada pada kategori tersebut.

Dari hasil analisis angket dan tes hasil belajar maka peneliti menarik kesimpulan tentang pelaksanaan siklus II yaitu telah terjadi perubahan dan dianggap bahwa untuk pelaksanaan model discovery learning dalam meningkatkan kesadaran metakognitif dan hasil belajar peserta didik dalam penelitian ini sudah cukup.

\section{e. Refleksi tindakan siklus II}

Berdasarkan data nilai dari pretest dan posttest angket, tes akhir siklus I dan siklus II, terlihat adanya peningkatan kemampuan pada pembelajaran IPS melalui model discovery learning. Berdasarkan data tersebut maka penelitian ini dinyatakan sudah berhasil mencapai target indikator keberhasilan dimana pada variabel hasil belajar 92,5\% peserta didik telah mencapai standar KKM yang telah ditentukan dan pada variabel kesadaran metakognitif sebagian besar siswa berada pada kategori berkembang baik dan berkembang sangat baik sebesar 74,07\%, sehingga dinyatakan tindakan pada siklus II dalam penelitian ini telah selesai.

\section{Pembahasan}

Berdasarkan pelaksanaan tindakan yang telah dilakukan oleh peneliti dalam mengimplementasikan model discovery learning untuk meningkatkan kesadaran metakognitif dan hasil belajar peserta didik pada pembelajaran IPS di kelas V SDN No. 79 Sawakong Towa Takalar telah menunjukkan perubahan yang ditandai dengan adanya peningkatan Kesadaran Metakognitif peserta didik melalui pengamatan langsung terhadap aktivitas keseharian siswa selama peneliti melakukan penelitian dimana dalam kesehariannya peserta didik sudah memiliki kebiasaan memperbanyak referensi ketika mengalami kesulitan dalam belajar, peserta didik terlihat membaca petunjuk dengan baik sebelum memulai suatu tugas, dan mampu mengatur waktu sebaik-baiknya agar tugas dapat selesai tepat waktu.

Hasil dari penelitian ini sesuai dengan pendapat Putri dkk (2012) yang menyatakan metakognitif merupakan kesadaran untuk berpikir, merencanakan, memantau dan merefleksikan tugas-tugas yang diselesaikan. Metakognitif dapat memancing proses berpikir siswa serta mendorong siswa untuk menilai pembelajaran yang dilakukan. Selain itu (Munandar, 2014) menyatakan bahwa kesadaran metakognitif merupakan kesadaran dari peserta didik untuk mengontrol proses berpikir dalam pembelajaran. Kesadaran metakognitif sangat penting diperhatikan oleh guru karena merupakan aspek yang sangat diperlukan guna mencapai kesuksesan belajar. Dengan kesadaran metakognitif yang dimiliki, maka peserta didik dapat melakukan persiapan, pemantauan, penilaian, maupun perbaikan pada proses pembelajarannya. Hal ini tentunya akan berpengaruh terhadap hasil belajar siswa.

Berdasarkan hasil penelitian dan pendapat di atas, tampak bahwa implementasi model discovery learning mampu meningkatkan kesadaran metakognitif peserta didik merupakan tindakan yang dapat dilakukan untuk membantu siswa dalam memecahkan masalah yang sedang dihadapi seperti yang telah peneliti lakukan. Meskipun dalam pelaksanaan penelitian ini terdapat kekurangan, seperti bahan bacaan sebagai bahan informasi untuk siswa yang diberikan 
oleh pimpinan kelompok semestinya direvisi setiap selesai pelaksanaan satu siklus, waktu yang dibutuhkan dalam penelitian ini sangat terbatas, sebagian siswa masih kurang menyadari akan pentingnya memahami bahan informasi yang diberikan.

Secara umum pembelajaran dengan menggunakan model discovery learning memiliki potensi yang cukup baik untuk meningkatkan hasil belajar peserta didik pada pembelajaran IPS. Meskipun pada tindakan siklus 1 keberhasilan siswa belum sesuai dengan yang diharapkan peneliti tetapi setelah melakukan revisi pada perangkat pembelajaran untuk penerapannya pada tindakan siklus 2 keberhasilan siswa sudah sesuai dengan harapan peneliti. Hal ini menujukkan bahwa implementasi model discovery learning mampu meningkatkan hasil belajar peserta didik pada pembelajaran IPS mengalami peningkatan yang cukup signifikan. Dengan demikian, model discovery learning merupakan model pembelajaran yang dapat meningkatkan hasil belajar peserta didik pada pembelajaran IPS.

Hal tersebut sejalan dengan pendapat (Kristin \& Rahayu, 2016) yang menyatakan bahwa discovery learning sebagai suatu model untuk mengembangkan cara belajar peserta didik dengan menemukan sendiri, menyelidiki sendiri, sehingga hasil yang diperoleh akan tahan lama dalam ingatan tidak akan mudah dilupakan oleh peserta didik. Dengan belajar penemuan peserta didik juga bisa berpikir lebih kritis dan mencoba memecahkan sendiri masalah yang dihadapi. Lebih lanjut lagi Salmon (2012:4) mengemukakan bahwa model discovery learning dalam pengaplikasiannya mengembangkan cara belajar siswa aktif dengan menemukan sendiri, menyelidiki sendiri, maka hasil yang diperoleh akan tahan lama dalam ingatan dan posisi guru sebagai pembimbing dan mengarahkan pembelajaran agar tercapai tujuan.

\section{SIMPULAN DAN SARAN}

Berdasarkan hasil penelitian tindakan yang telah dilakukan peneliti di kelas V SDN No. 79 Sawakong Towa Takalar, maka dapat disimpulkan bahwa pengimplementasian model discovery learning merupakan salah satu model pembelajaran yang dapat diterapkan untuk meningkatkan kesadaran metakognitif peserta didik sehingga peserta didik terdorong untuk memikirkan cara belajar yang baik untuk dilakukan.

Dengan pengimplementasian model discovery learning Aktivitas dan hasil belajar siswa meningkat secara signifikan pada pembelajaran IPS di kelas V SDN No. 79 Sawakong Towa Takalar. Setiap siklusnya mengalami peningkatan dan pada proses pembelajarnnya peserta didik mendapat pengetahuan yang bermakna.

Sehubungan dengan simpulan penelitian di atas, maka disarankan sebagai berikut: (1) Bagi praktisi pendidikan (guru) yang tertarik untuk menerapkan model discovery learning dalam pembelajaran IPS, disarankan memperhatikan hal-hal sebagai berikut: a) Perlu mengalokasikan waktu secara baik, karena kegiatan diskusi untuk menyelesaikan masalah apabila tidak dibatasi waktunya siswa akan lama dalam diskusi, di samping itu guru hendaknya selalu memantau kegiatan diskusi siswa, sehingga tahu apa yang dilakukan siswa; b) Guru dalam menggunakan model discovery learning dalam pembelajaran IPS hendaknya menggunakan alat peraga yang sesuai dengan materi yang akan diajarkan, sehingga siswa lebih mudah memahami materi yang diajarkan. 2) Bagi peneliti lain yang ingin mengangkat kembali implementasi model discovery learning dalam pembelajaran hendaknya penelitian ini dapat dijadikan sebagai pedoman dengan memperhatikan kekurangan-kekurangan dan kelebihankelebihan yang terdapat di dalam pelaksanaannya, sehingga dapat dijadikan sebagai bahan pertimbangan dan refleksi awal demi penyempurnaan penelitian selanjutnya. Dan sebaiknya mencobakan pada materi berbeda yang sesuai dengan karakteristik model discovery learning.

\section{DAFTAR RUJUKAN}

Arifah, A. N. \& Saenab, S. 2014. Perbandingan Kesadaran Metakognitif Siswa yang Diajar Menggunakan Model Problem-Based Instruction (PBI) dengan Kooperatif Tipe Think Pair Share (TPS). Jurnal Bionature, Vol. 15, No. 2, 81-89. 
Balim, A. G. 2009. The Effects of Discovery Learning on Students' Success and Inquiry Learning Skills. Egitim Arastirmalari-Eurasian Journal of Educational Research, Vol. 3, No. 5.

Hala, Y., \& Taiyeb, A. M. 2016. Penerapan Model Pembelajaran Kooperatif Tipe Make A Match Untuk Meningkatkan Motivasi, Aktivitas, Dan Hasil Belajar Biologi Kelas X. 1 Sman 1 Dua Boccoe Kabupaten Bone. Jurnal Nalar Pendidikan, No.4, Vol. 2.

Hamid, H., Nurhayati, B., \& Ali, A. 2015. Peningkatan Aktivitas, Hasil Belajar Afektif dan Kognitif pada Mata Pelajaran Biologi melalui Penerapan Model Brain Based Learning Peserta Didik Kelas VII-A SMP Negeri $4 \quad$ Sungguminasa Kabupaten Gowa. Sainsmat, Vol. 3, No. 1.

Kristin, F., \& Rahayu, D. 2016. Pengaruh penerapan model discovery learning terhadap hasil belajar IPS pada siswa kelas IV SD. Jurnal ilmiah kependidikan, Vol. 6, No 1.

Munandar, H. 2014. Hubungan Kesadaran Metakognitif dan Gaya Kognitif dengan Kemampuan Metakognitif Peserta Didik Kelas XI IPA SMA Negeri di Kota Pare-Pare. Tesis. Tidak diterbitkan. Makassar: Program Pascasarjana Universitas Negeri Makassar.

Purwanto. 2011. Evaluasi Hasil Belajar. Yogyakarta: Pustaka Pelajar.

Putri, W. A, Andreas P. B. P \& Supriyanto. 2012. Pengaruh Penerapan Strategi Metakognitif dalam Metode Inkuiri terhadap Hasil Belajar. Unnes Journal of Biology Education, 1 (3), 266-271.

Silberman, M. L. 2013. Active Learning (Strategi Pembelajaran Aktif). Yogyakarta: Nusa Media.

Sukaisih, R. \& Muhali. 2013. Meningkatkan Kesadaran Metakognitif dan Hasil Belajar Siswa Melalui Penerapan Pembelajaran Problem Solving. Jurnal Pengkajian Ilmu dan Pembelajaran Matematika dan IPA "PRISMA SAINS", Vol. 2, No. 1, 244-255.

Tapantoko, A. A. 2011. Penggunaan Metode Mind Map (Peta Pikiran) Untuk Meningkatkan Motivasi Belajar Siswa Dalam Pembelajaran Matematika Siswa Kelas VIII SMP Negeri 4 Depok. Disertasi. Dipublikasi. Yogyakarta: Universitas Negeri Yogyakarta. 